\title{
Hubungan Kondisi Jamban Keluarga Dan Sarana Air Bersih Dengan Kejadian Diare Pada Balita Di Wilayah Kerja Puskesmas Arosbaya Bangkalan
}

\author{
Saktya Yudha Ardhi Utama ${ }^{1}$, Aini Inayati ${ }^{2}$ Sugiarto $^{3}$ \\ 1,2,3 Program Studi Profesi Ners, Universitas Alma Ata Yogyakarta \\ Jl. Brawijaya 99 Yogyakarta
}

Email : saktya_yudha@yahoo.com

\begin{abstract}
Abstrak
Latar Belakang: Diare masih merupakan penyebab kematian balita di Indonesia. Masalah kesehatan seperti diare dapat dicegah, jika masyarakat mempraktikkan perilaku hidup sehat dan berpartisipasi dalam menjaga sanitasi lingkungan. Jumlah diare pada balita di Puskesmas Arosbaya terjadi peningkatan.

Objektif: Tujuan dari penelitian ini untuk mengetahui hubungan kondisi jamban keluarga dan sarana air bersih dengan kejadian diare pada balita.

Metode: Penelitian ini merupakan penelitian deskriptif analitik dengan desain cross sectional. Populasi dalam penelitian ini adalah keluarga dengan anak balita yang tinggal di daerah Arosbaya dengan sampel yang digunakan 21 responden yang dihitung dengan menggunakan purposive sampling. Analisis yang digunakan adalah uji statistik korelasi spearman's rho.

Hasil: Hasil ini menunjukkan bahwa ada hubungan antara kondisi jamban keluarga dengan kejadian diare pada balita $(\mathrm{p}=0.001)$. Hasil penelitian menunjukkan bahwa ada hubungan antara kondisi sarana air bersih dengan kejadian diare pada balita $(p=0,009)$.

Kesimpulan: Kesimpulan dari penelitian ini adalah bahwa jamban keluarga dan sarana air bersih yang buruk berhubungan dan mendorong diare pada anak balita. Dari penelitian ini disarankan untuk memperbaiki sanitasi lingkungan seperti jamban keluarga dan sarana air bersih untuk mengurangi diare.
\end{abstract}

Kata kunci : Balita, diare, jamban keluarga, sarana air bersih, 


\section{The Correlation of Condition of Family Latrine and Clean Water Facilities With Occurrence of Diarrhea in Under Five-Children at Public Health Center of Arosbaya Bangkalan}

\section{Abstract}

Background: Diarrhea is still a cause of under-five children mortality in Indonesia. Health problems such as diarrhea can be prevented, if the community practice healthy behaviour and participate in taking care of the environmental sanitation. The number of diarrhea in children under five at Puskesmas Arosbaya has increase.

Objective: This study aims to analyze the correlation of condition of family latrine and clean water facilities with occurence of diarrhea in under-five children.

Method: This study was an descriptive analytic research using cross sectional design. The population of this study was families with under-five children that live in Arosbaya region with sample consisted 21 respondents which are counted using purposive sampling. The analysis used was Spearman's rho correlation statistic test.

Result: This result showed that there was a correlation between the condition of family latrine with occurence of diarrhea in under-five children $(p=0,001)$. And the result of study showed that there was a correlation between the condition of clean water facilities with occurence of diarrhea in underfive children $(p=0,009)$.

Conclusion: The conclusion of this study was that bad family latrine dan clean water facilities are related and encourages the diarrhea in under-five children. From this study suggested to repair environmental sanitation such as family latrine and clean water facilities to decrease diarrhea.

Keyword: family latrine, clean water facilities, diarrhea, under-five children.

\section{PENDAHULUAN}

Penyakit diare sampai saat ini masih merupakan salah satu penyebab utama kesakitan dan kematian. Hampir di seluruh daerah di dunia dan semua kelompok usia diserang oleh diare, tetapi kebanyakan yang menjadi sasaran penyakit ini adalah bayi dan anak balita, dimana mereka mengalami ratarata 3-4 kali kejadian diare per tahun atau hampir 15-20\% waktu hidup anak dihabiskan untuk diare (Soebagyo, 2013).
Pada umumnya diare ini sangat terkait dengan kondisi lingkungan. Penjagaan terhadap kebersihan lingkungan menjadi faktor utama untuk langkah pencegahan (Akhmad, 2012).

Di Indonesia, banyak Sarana Air Bersih (SAB) dan sanitasi tidak berfungsi dengan baik. Permasalahan ini antara lain disebabkan oleh kualitas konstruksi, pengelolaan yang tidak jelas dan masyarakat kurang terlibat dalam proses pembangunan. Sebagian besar masyarakat tidak memiliki akses yang 
Dinamika Kesehatan Jurnal Kebidanan dan Keperawatan Vol 10 No. 2 Desember 2019 ( ISSN: 2086-3454 EISSN: 2549-4058)

url: http://ojs.dinamikakesehatan.unism.ac.id DOI: https://doi.org/10.33859/dksm.v10i2

Hubungan Kondisi Jamban Keluarga Dan Sarana Air Bersih Dengan Kejadian Diare Pada Balita

Di Wilayah Kerja Puskesmas Arosbaya Bangkalan

memadai terhadap air, serta memiliki

kebersihan pribadi yang buruk sehingga

beresiko terhadap penyakit menular yang

terkait dengan air (Kanaf, dkk, 2011).

Dari data yang diperoleh kasus diare di

Puskesmas Arosbaya menduduki peringkat ketiga setelah ISPA dan radang pulpa atau penyakit priodental. Upaya pemerintah untuk penanggulangan diare sudah dilakukan melalui penetapan program maupun strategi penanggulangan penyakit diare dengan sasaran pada kelompok masyarakat yang berisiko tinggi karena kondisi lingkungan yang kurang menguntungkan, daerah rawan penyakit yang ditandai dengan tingginya prevalensi kejadian diare, baik melalui program proyek tertinggal maupun proyek lainnya. Namun sampai saat ini belum mencapai tujuan yang diharapkan. Kondisi kesehatan lingkungan di wilayah Arosbaya juga masih rendah, dimana cakupan jamban keluarga dan air bersih masih di bawah angka standar karena berdasarkan indikator Puskesmas Arosbaya standar cakupan jamban keluarga adalah $70 \%$ sedangkan standar cakupan air bersih adalah $80 \%$.

Masyarakat memandang jamban keluarga dan sarana air bersih bukan sebagai suatu kebutuhan yang penting bagi kesehatan. Kegiatan BAB masih banyak dilakukan masyarakat di sungai-sungai sekitar rumah mereka. Kebiasaan yang sudah melekat sejak lama itu yang masih belum bisa dirubah meskipun secara tidak langsung banyak kerugian yang ditimbulkan akibat kebiasaan perilaku tersebut. Sementara itu, kondisi air bersih juga belum menjadi perhatian utama masyarakat, masih minimnya sarana air bersih yang memenuhi syarat sehingga mengakibatkan masih adanya masyarakat yang melakukan aktivitas mencuci pakaian ataupun makanan di daerah sungai. Banyak faktor yang secara langsung maupun tidak langsung menjadi pendorong terjadinya diare yaitu faktor agent, penjamu, lingkungan dan perilaku (Depkes, 2013). Faktor lingkungan merupakan faktor yang paling dominan yaitu sarana penyediaan air bersih dan pembuangan tinja, kedua faktor berinteraksi bersama 
Dinamika Kesehatan Jurnal Kebidanan dan Keperawatan Vol 10 No. 2 Desember 2019 ( ISSN: 2086-3454 EISSN: 2549-4058)

url: http://ojs.dinamikakesehatan.unism.ac.id DOI: https://doi.org/10.33859/dksm.v10i2

Hubungan Kondisi Jamban Keluarga Dan Sarana Air Bersih Dengan Kejadian Diare Pada Balita

Di Wilayah Kerja Puskesmas Arosbaya Bangkalan

dengan perilaku manusia. Apabila faktor lingkungan tidak sehat karena tercemar kuman diare serta terakumulasi dengan perilaku manusia yang tidak sehat, maka penularan diare dengan mudah dapat terjadi (Chandra, 2013). Hal ini sejalan dengan konsep segitiga epidemiologi (John Gordon, 1950) yang menerangkan bahwa suatu penyakit timbul akibat interaksi satu sama lain yaitu lingkungan, agen dan host. Jika kemampuan agen meningkat maka dapat menginfeksi manusia serta mengakibatkan penyakit pada manusia. Perubahan lingkungan yang buruk juga dapat menyebabkan meningkatnya perkembangan agen (Timmreck, 2004).

Untuk mencegah terjadinya peningkatan kejadian penyakit berbasis lingkungan dalam rangka mewujudkan kesehatan individu, keluarga dan masyarakat seperti yang diharapkan, maka diperlukan ketersediaan sarana sanitasi dasar seperti air bersih, pemanfaatan jamban, pembuangan air limbah, pembuangan sampah, rumah dan lingkungan yang sehat serta membudayakan perilaku hidup bersih dan sehat dalam kehidupan sehari-hari (Cha, et al, 2016).

\section{METODE}

Jenis penelitian ini menggunakan rancangan deskriptif analitik dengan pendeketan Cross Sectional. Terdapat 21 responden keluarga yang memiliki balita dan pernah mengalami diare selama satu bulan terakhir untuk penelitian ini. Pengambilan sampel dengan teknik purposive sampling. Variabel independen dalam penelitian ini adalah kondisi jamban keluarga dan sarana air bersih. Variabel dependen dalam penelitian ini adalah kejadian diare pada balita. Pengumpulan data dilakukan dengan menggunakan instrumen lembar observasi yang terdiri dari dua lembar observasi yaitu lembar observasi jamban keluarga yang terdiri dari 5 pengamatan dan lembar observasi sarana air bersih terdiri dari 3 pengamatan. Untuk mengetahui hubungan antara variabel independen dengan dependen, yaitu kondisi jamban keluarga dan sarana air bersih dengan kejadian diare pada balita di wilayah kerja puskesmas Arosbaya Bangkalan, maka uji 
Dinamika Kesehatan Jurnal Kebidanan dan Keperawatan Vol 10 No. 2 Desember 2019 ( ISSN: 2086-3454 EISSN: 2549-4058)

url: http://ojs.dinamikakesehatan.unism.ac.id DOI: https://doi.org/10.33859/dksm.v10i2

Hubungan Kondisi Jamban Keluarga Dan Sarana Air Bersih Dengan Kejadian Diare Pada Balita Di Wilayah Kerja Puskesmas Arosbaya Bangkalan

statistik yang digunakan adalah uji statistik korelasi Spearman's Rho dengan $\alpha \leq 0,05$, artinya jika $\mathrm{p} \leq 0,05 \mathrm{H} 1$ diterima, berarti ada hubungan antara kondisi jamban keluarga dan sarana air bersih dengan kejadian diare pada balita.

\section{HASIL}

1. Distribusi responden berdasarkan kategori tingkat pendidikan

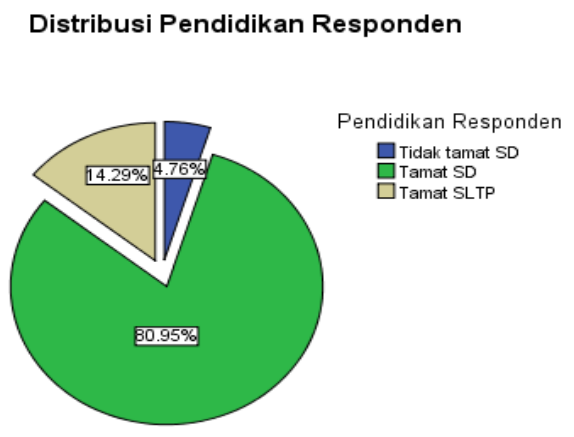

Gambar 1 Distribusi pendidikan responden di wilayah kerja Puskesmas Arosbaya

Gambar 1 menunjukkan bahwa dari 21 responden, yang terlihat paling banyak adalah responden yang berlatar pendidikan tamat SD yaitu 17 responden $(80,95 \%)$. dan hanya sebagian kecil sebanyak 1 responden $(4,76 \%)$ tidak tamat SD.
2. Distribusi responden berdasarkan jenis pekerjaan

Distribusi Pekerjaan Responden

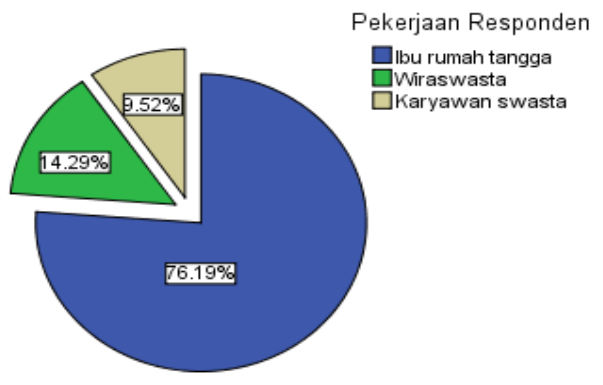

Gambar 2 Distribusi pekerjaan responden di wilayah kerja Puskesmas Arosbaya

Gambar 2 menunjukkan bahwa dari 21 responden, yang terlihat paling banyak adalah responden yang memiliki pekerjaan sebagai ibu rumah tangga sebanyak 16 responden $(76,19 \%)$ dan terkecil sebanyak 2 responden $(9,52 \%)$ bermata pencaharian sebagai karyawan swasta.

3. Distribusi responden berdasarkan usia balita

\section{Distribusi Usia Balita Responden}

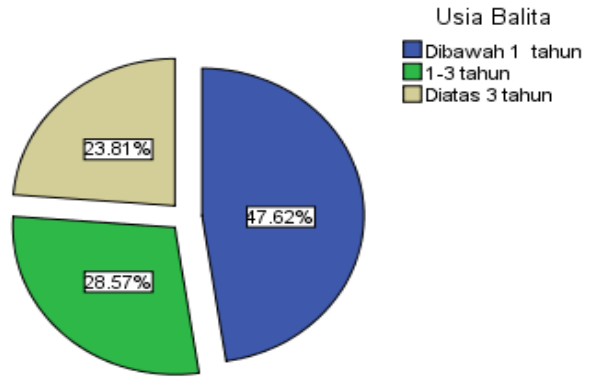

Gambar 3 Distribusi usia balita responden di wilayah kerja Puskesmas Arosbaya 
Dinamika Kesehatan Jurnal Kebidanan dan Keperawatan Vol 10 No. 2 Desember 2019 ( ISSN: 2086-3454 EISSN: 2549-4058)

url: http://ojs.dinamikakesehatan.unism.ac.id DOI: https://doi.org/10.33859/dksm.v10i2

Hubungan Kondisi Jamban Keluarga Dan Sarana Air Bersih Dengan Kejadian Diare Pada Balita

Di Wilayah Kerja Puskesmas Arosbaya Bangkalan

Gambar 3 menunjukkan bahwa dari 21

responden, yang terlihat sebagian besar adalah anak balita dengan rentang usia dibawah 1 tahun sebanyak 10 responden $(47,62 \%)$ dan terkecil sebanyak 5 responden $(23,81 \%)$ dengan dengan usia diatas 3 tahun.

4. Identifikasi jamban keluarga

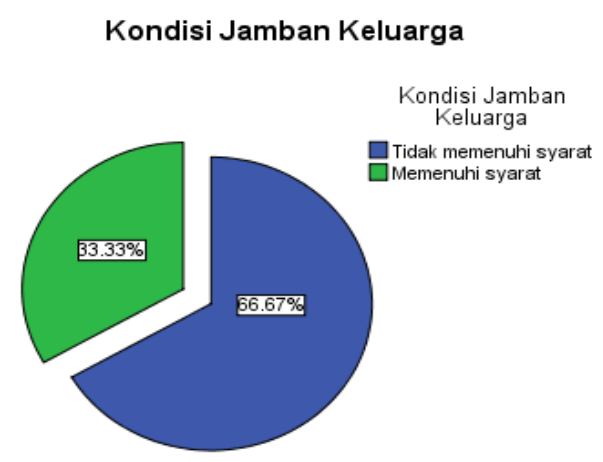

Gambar 4 Distribusi kondisi jamban keluarga di wilayah kerja Puskesmas Arosbaya

Gambar 4 menunjukkan bahwa kondisi jamban keluarga yang memenuhi syarat sebanyak 7 responden $(33,33 \%)$ dan jumlah jamban keluarga yang tidak memenuhi syarat sebanyak 14 responden ( 66,67\%).

5. Identifikasi sarana air bersih
Kondisi Sarana Air Bersih

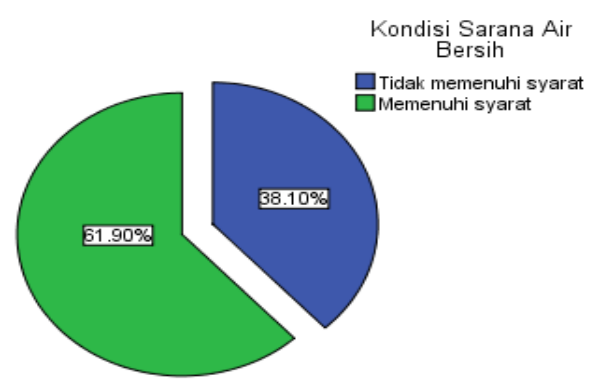

Gambar 5 Distribusi kondisi sarana air bersih di wilayah kerja Puskesmas Arosbaya

Gambar 5 menunjukkan bahwa kondisi sarana air bersih yang memenuhi syarat sebanyak 13 responden $(61,9 \%)$ dan jumlah sarana air bersih yang tidak memenuhi syarat sebanyak 8 responden $(38,1 \%)$.

6. Identifikasi kejadian diare pada balita

Kejadian Diare Balita

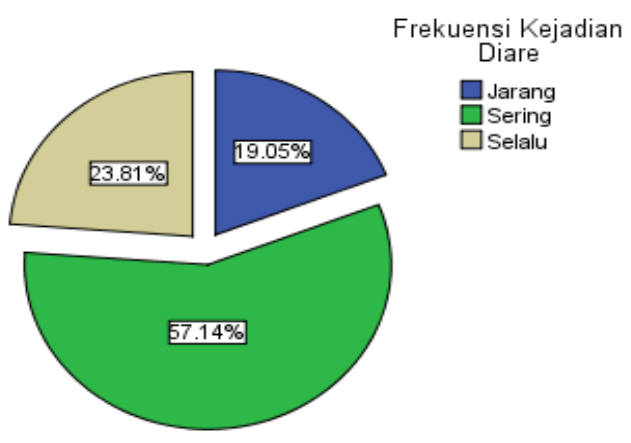

Gambar 6 Distribusi kejadian diare pada balita di wilayah kerja Puskesmas Arosbaya

Gambar 6 menunjukkan bahwa sebagian besar mengalami diare dengan frekuensi sering sebanyak 12 balita $(57,14 \%)$ dan sebagian kecil yang mengalami diare dengan frekuensi jarang sejumlah 4 balita $(19,05 \%)$. 
Dinamika Kesehatan Jurnal Kebidanan dan Keperawatan Vol 10 No. 2 Desember 2019 ( ISSN: 2086-3454 EISSN: 2549-4058)

url: http://ojs.dinamikakesehatan.unism.ac.id DOI: https://doi.org/10.33859/dksm.v10i2

Hubungan Kondisi Jamban Keluarga Dan Sarana Air Bersih Dengan Kejadian Diare Pada Balita

Di Wilayah Kerja Puskesmas Arosbaya Bangkalan

7. Tabulasi silang kondisi jamban keluarga dengan kejadian diare pada balita di wilayah kerja Puskesmas Arosbaya .

Tabel 1 Hubungan kondisi jamban keluarga dengan kejadian diare pada balita di wilayah kerja Puskesmas Arosbaya

\begin{tabular}{|c|c|c|c|c|c|c|c|c|c|}
\hline \multirow[t]{3}{*}{ No. } & \multirow{3}{*}{$\begin{array}{c}\text { Jamban } \\
\text { Keluarga }\end{array}$} & \multicolumn{6}{|c|}{ Kejadian Diare pada Balita } & \multirow[t]{3}{*}{ Total } & \multirow{3}{*}{$\begin{array}{c}\text { Persent } \\
\text { ase }\end{array}$} \\
\hline & & \multicolumn{2}{|c|}{ Jarang } & \multicolumn{2}{|c|}{ Sering } & \multicolumn{2}{|c|}{ Selalu } & & \\
\hline & & $\sum$ & $\%$ & $\sum$ & $\%$ & $\sum$ & $\%$ & & \\
\hline 1 & $\begin{array}{l}\text { Tidak } \\
\text { memenuhi } \\
\text { syarat }\end{array}$ & 0 & $0 \%$ & 9 & $42,9 \%$ & 5 & $23,8 \%$ & 14 & $66,7 \%$ \\
\hline 2 & $\begin{array}{l}\text { Memenuhi } \\
\text { syarat }\end{array}$ & 4 & $19 \%$ & 3 & $14,3 \%$ & 0 & $0 \%$ & 7 & $33,3 \%$ \\
\hline \multirow{2}{*}{\multicolumn{2}{|c|}{ Jumlah }} & 4 & $19 \%$ & 12 & $57,2 \%$ & 5 & $23,8 \%$ & 21 & $100 \%$ \\
\hline & & & & $\overline{0,00}$ & $\mathrm{r}=0$ & & & & \\
\hline
\end{tabular}

Tabel 1 diatas menunjukkan hasil uji

statistik Spearmen's Rank pada penelitian hubungan kondisi jamban keluarga dengan kejadian diare pada balita menunjukkan terdapat hubungan yang signifikan antara kondisi jamban keluarga dengan kejadian diare pada balita di wilayah kerja Puskesmas Arosbaya Bangkalan dengan tingkat hubungan yang cukup kuat $\quad(r=0,664$ dan $\rho=0,001)$. Hal ini menunjukkan bahwa semakin baik kondisi jamban keluarga maka kejadian diare pada balita semakin menurun.
8. Tabulasi silang kondisi jamban sarana air bersih dengan kejadian diare pada balita di wilayah kerja Puskesmas Arosbaya.

Tabel 2 Hubungan kondisi sarana air bersih dengan kejadian diare pada balita di wilayah kerja Puskesmas Arosbaya

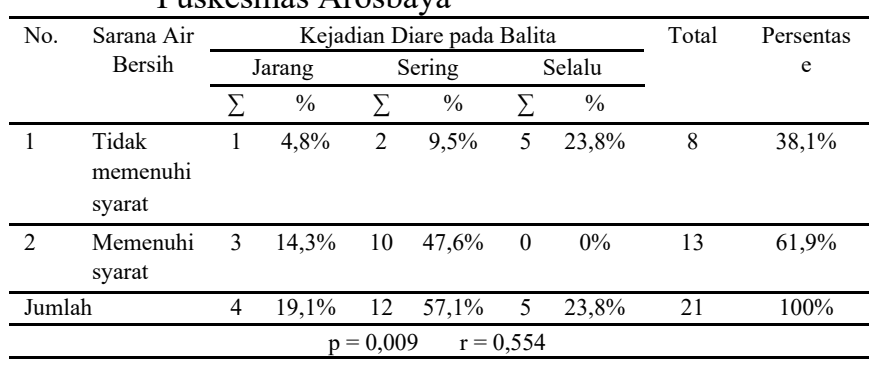

Tabel 2 diatas menunjukkan hasil uji statistik Spearmen's Rank pada penelitian hubungan kondisi sarana air bersih dengan kejadian diare pada balita menunjukkan terdapat hubungan yang signifikan antara kondisi sarana air bersih dengan kejadian diare pada balita di wilayah kerja Puskesmas Arosbaya Bangkalan dengan tingkat hubungan sedang $\quad(\mathrm{r}=0,554$ dan $\rho=$ 0,009). Hal ini menunjukkan bahwa semakin baik kondisi sarana air bersih maka kejadian diare pada balita semakin menurun.

\section{PEMBAHASAN}

\section{Kondisi jamban keluarga.}

Hasil analisa data menunjukkan lebih dari setengah jumlah responden penelitian memiliki jamban keluarga yang tidak memenuhi syarat, hal ini dapat dibuktikan dari 
Dinamika Kesehatan Jurnal Kebidanan dan Keperawatan Vol 10 No. 2 Desember 2019 ( ISSN: 2086-3454 EISSN: 2549-4058) url: http://ojs.dinamikakesehatan.unism.ac.id DOI: https://doi.org/10.33859/dksm.v10i2

Hubungan Kondisi Jamban Keluarga Dan Sarana Air Bersih Dengan Kejadian Diare Pada Balita

Di Wilayah Kerja Puskesmas Arosbaya Bangkalan

hasil rekapitulasi nilai observasi jamban keluarga yang memiliki nilai rata-rata rendah dibawah angka standar (kurang dari 8). Sedangkan sisanya memiliki jamban keluarga yang memenuhi syarat dengan rekapitulasi nilai observasi antara 8-10. Dari hasil data demografi responden diperoleh bahwa mayoritas pendidikan responden adalah tamat Sekolah Dasar (SD) sebanyak 17 responden (81\%) yang termasuk golongan pendidikan tingkat menengah ke bawah.

Menurut Notoatmodjo (2014), tingkat pendidikan seseorang dapat meningkatkan pengetahuannya tentang kesehatan. Salah satu faktor yang mempengaruhi pengetahuan seseorang adalah tingkat pendidikan. Pendidikan akan memberikan pengetahuan sehingga terjadi perubahan perilaku positif yang meningkat. Menurut Widyastuti (2005), orang yang memiliki tingkat pendidikan lebih tinggi lebih berorientasi pada tindakan preventif, mengetahui lebih banyak tentang masalah kesehatan dan memiliki status kesehatan yang lebih baik. Melihat dari data diatas, sebaiknya masyarakat perlu diberikan pengetahuan tentang pentingnya peranan jamban keluarga melalui penyuluhan yang dilakukan oleh petugas maupun kader lingkungan di wilayah Arosbaya dan bagi mereka yang telah memiliki jamban keluarga yang memenuhi syarat tetap perlu mendapatkan motivasi agar selalu memelihara dan mempertahankan kebersihan jamban keluarga.

\section{Kondisi sarana air bersih.}

Hasil analisa data menunjukkan lebih dari setengah jumlah responden penelitian memiliki sarana air bersih yang memenuhi syarat, hal ini dapat dibuktikan dari hasil rekapitulasi nilai observasi jamban keluarga yang memiliki nilai rata-rata sesuai nilai standar (antara 2 - 3). Sedangkan sisanya memiliki sarana air bersih yang tidak memenuhi syarat dengan rekapitulasi nilai observasi kurang dari 2. Dari hasil data demografi jenis pekerjaan diperoleh sebagian besar responden sebagai ibu rumah tangga sebanyak 16 responden $(76,2 \%)$ hanya sebagian yang bekerja sebagai wiraswasta 
Dinamika Kesehatan Jurnal Kebidanan dan Keperawatan Vol 10 No. 2 Desember 2019 ( ISSN: 2086-3454 EISSN: 2549-4058) url: http://ojs.dinamikakesehatan.unism.ac.id DOI: https://doi.org/10.33859/dksm.v10i2

Hubungan Kondisi Jamban Keluarga Dan Sarana Air Bersih Dengan Kejadian Diare Pada Balita

Di Wilayah Kerja Puskesmas Arosbaya Bangkalan

sebanyak 3 responden (14,3\%) dan karyawan

swasta sebanyak 2 responden $(9,5 \%)$.

Karakteristik pekerjaan seseorang dapat mencerminkan pendapatan, status sosial dan status sosial ekonomi. Status pekerjaan seseorang juga mempengaruhi kemampuan seseorang untuk memelihara kesehatannya dalam hal ini biaya yang dikeluarkan untuk memenuhi kesehatannya (Widyastuti, 2005).

Melihat dari data diatas, maka perlu upaya dari masyarakat untuk selalu menjaga kondisi sumur gali dengan melakukan perawatan secara teratur dengan membersihkan bagian-bagian sumur gali yang ditumbuhi oleh lumut dan jamur supaya kulaitas fisik air sumur gali tetap terjaga. Selain itu, lantai di sekitar sumur gali harus selalu bersih, timba dan tali dibersihkan secara rutin supaya tidak mencemari air.

\section{Hubungan kondisi jamban keluarga dengan kejadian diare pada balita.}

Berdasarkan uji statistik Spearman's Rho dengan nilai $\mathrm{p}=0,001$ maka $\mathrm{p}<0,05$ dapat disimpulkan hipotesis diterima yang berarti ada hubungan antara kondisi jamban keluarga dengan kejadian diare pada balita sedangkan koefisien korelasinya adalah 0.664 yang berarti tingkat hubungan kedua variabel adalah kuat.

Dengan kondisi jamban keluarga yang belum memenuhi syarat, dapat menyebabkan timbulnya kejadian diare pada balita responden yang disebabkan kotoran tinja yang tidak terkubur rapat akan mengundang lalat maupun tikus yang akan berdampak terhadap kesehatan lingkungan. Hasil penelitian ini dapat dijelaskan bahwa kejadian diare pada balita dipengaruhi oleh kondisi lingkungan yang tidak baik, dalam hal ini adalah kondisi jamban keluarga mempengaruhi kejadian diare pada balita. Hal ini sesuai dengan konsep segitiga epidemiologi (John Gordon, 1950) yang menerangkan bahwa suatu penyakit timbul akibat interaksi satu sama lain yaitu lingkungan, agen dan host. Jika kemampuan agen meningkat maka dapat menginfeksi manusia serta mengakibatkan penyakit pada manusia. Perubahan lingkungan yang buruk juga dapat menyebabkan meningkatnya perkembangan 
Dinamika Kesehatan Jurnal Kebidanan dan Keperawatan Vol 10 No. 2 Desember 2019 ( ISSN: 2086-3454 EISSN: 2549-4058) url: http://ojs.dinamikakesehatan.unism.ac.id DOI: https://doi.org/10.33859/dksm.v10i2

Hubungan Kondisi Jamban Keluarga Dan Sarana Air Bersih Dengan Kejadian Diare Pada Balita

Di Wilayah Kerja Puskesmas Arosbaya Bangkalan

agen (Timmreck, 2004). Pernyataan lain yaitu

Soemirat (2014) menyimpulkan bahwa selain sumber air minum tempat pembuangan tinja juga merupakan sarana sanitasi yang penting dalam mempengaruhi kejadian diare. Membuang tinja yang tidak memenuhi syarat sanitasi dapat mencemari lingkungan pemukiman, tanah dan sumber air.

$$
\text { Masalah penyehatan lingkungan }
$$

merupakan salah satu dari berbagai masalah kesehatan yang perlu mendapatkan prioritas karena dapat menjadi media bibit penyakit. Diare sering menyebabkan wabah yang dapat membahayakan bagi penderita maupun orangorang di sekitarnya yang bertempat tinggal di daerah-daerah yang sanitasi lingkungannya kurang memenuhi syarat kesehatan. Penyediaan jamban keluarga dalam masyarakat terutama dalam pelaksanaannya tidaklah mudah, oleh karena itu perlu upaya kerja sama yang sinergis antara masyarakat dan pemerintah dalam upaya peningkatan sanitasi lingkungan.

\section{Hubungan kondisi sarana air bersih}

dengan kejadian diare pada balita.

Berdasarkan uji statistik Spearman's Rho dengan nilai $\mathrm{p}=0,009$ maka $\mathrm{p}<0,05$ dapat disimpulkan hipotesis diterima yang berarti ada hubungan antara kondisi sarana air bersih dengan kejadian diare pada balita sedangkan koefisien korelasinya adalah 0,554 yang berarti tingkat hubungan kedua variabel adalah sedang.

Hasil analisa data diperoleh bahwa kondisi sarana air bersih yang memenuhi syarat menunjukkan kejadian diare terbanyak pada kategori sering dan tidak ada kejadian diare pada kategori selalu sedangkan kondisi sarana air bersih yang tidak memenuhi syarat menunjukkan kejadian diare terbanyak pada kategori selalu dan terendah pada kategori jarang. Berdasarkan hasil data demografi diperoleh bahwa sebagian besar responden adalah tamat SD yang termasuk dalam kategori tingkat pendidikan menengah ke bawah. Pemanfaatan sarana sanitasi lingkungan sangat dipengaruhi oleh tingkat pendidikan masyarakat. Pendidikan 
Dinamika Kesehatan Jurnal Kebidanan dan Keperawatan Vol 10 No. 2 Desember 2019 ( ISSN: 2086-3454 EISSN: 2549-4058) url: http://ojs.dinamikakesehatan.unism.ac.id DOI: https://doi.org/10.33859/dksm.v10i2

Hubungan Kondisi Jamban Keluarga Dan Sarana Air Bersih Dengan Kejadian Diare Pada Balita Di Wilayah Kerja Puskesmas Arosbaya Bangkalan

masyarakat yang rendah menjadikan mereka sulit diajarkan mengenai pentingnya higyene perorangan dan sanitasi lingkungan untuk mencegah terjangkitnya penyakit menular, diantaranya diare. Dengan sulitnya mereka menerima penyuluhan, menyebabkan mereka tidak peduli terhadap upaya pencegahan penyakit menular (Sander, 2005).

Hasil tersebut juga sesuai dengan pernyataan Cha, et al (2016) yang menyatakan sumber air minum utama merupakan salah satu sarana sanitasi yang berkaitan dengan kejadian diare. Sebagian kuman infeksius penyebab diare ditularkan melalui jalur fekal oral. Hasil penelitian ini juga sejalan dengan pernyataan (Soemirat, 2014) yang menyebutkan salah satu faktor lingkungan yang berhubungan dengan terjadinya diare adalah air dan makanan. Air yang dapat menimbulkan dan menularkan penyakit diare adalah air yang tercemar oleh kuman penyebab diare.

Masalah penyehatan lingkungan merupakan salah satu dari berbagai masalah kesehatan yang perlu mendapatkan prioritas karena dapat menjadi media bibit penyakit.

Diare sering menyebabkan wabah yang dapat membahayakan bagi penderita maupun orangorang di sekitarnya yang bertempat tinggal di daerah-daerah yang sanitasi lingkungannya kurang memenuhi syarat kesehatan. Penyediaan sarana sarana air bersih masyarakat terutama dalam pelaksanaannya tidaklah mudah, karena menyangkut peran serta masyarakat yang biasanya sangat erat kaitannya dengan perilaku, tingkat ekonomi, kebudayaan dan pendidikan. Oleh karena itu diharapkan masyarakat beserta dengan pihakpihak yang terkait (Dinas Kesehatan Kabupaten / Puskesmas) saling bekerja sama dan mendukung dalam upaya peningkatan sanitasi lingkungan terutama sarana air bersih.

\section{SIMPULAN DAN SARAN}

\section{Simpulan}

1. Kondisi jamban keluarga yang digunakan oleh responden sebagian besar tidak memenuhi syarat.

2. Kondisi sarana air bersih yang digunakan oleh responden sebagian besar telah memenuhi syarat. 
Dinamika Kesehatan Jurnal Kebidanan dan Keperawatan Vol 10 No. 2 Desember 2019 ( ISSN: 2086-3454 EISSN: 2549-4058) url: http://ojs.dinamikakesehatan.unism.ac.id DOI: https://doi.org/10.33859/dksm.v10i2

Hubungan Kondisi Jamban Keluarga Dan Sarana Air Bersih Dengan Kejadian Diare Pada Balita Di Wilayah Kerja Puskesmas Arosbaya Bangkalan

3. Kejadian diare pada balita responden terbanyak pada frekuensi sering.

4. Kondisi jamban keluarga yang memenuhi syarat akan mengurangi frekuensi kejadian diare pada balita begitu juga sebaliknya.

5. Kondisi sarana air bersih yang memenuhi syarat akan mengurangi frekuensi kejadian diare pada balita begitu juga sebaliknya.

\section{Saran}

1. Bagi instansi kesehatan

Diharapkan bagi instansi kesehatan (Puskesmas) untuk dapat melakukan pemberdayaan masyarakat, dalam hal ini membentuk kader lingkungan dalam upaya peningkatan sanitasi lingkungan seperti kebersihan jamban keluarga dan sarana air bersih.

2. Bagi responden

Meningkatkan tindakan pencegahan terjadinya diare pada balita dengan menjaga kebersihan jamban keluarga dan sarana air bersih.
3. Bagi peneliti lain

Mengadakan penelitian lebih lanjut mengenai permasalahan yang sama, namun dengan variabel yang lain dalam hubungannya kejadian diare pada balita dengan menambahkan faktor sosial ekonomi, faktor perilaku dan status gizi balita.

\section{DAFTAR PUSTAKA}

Akhmad, S, 2012. 15 Langkah Jitu Menjaga Kesehatan Anak Sejak Bayi. Yogyakarta : Pelangi Multi Aksara.

Cha, et al. 2016. The Effect of Improved Sanitation on Diarrheal Prevalence, Incidence and Duration in Children Under Five in the SNNPR State, Ethiopia : Study Protocol for A Randomized Controlled Trial. Bio Med Central. 27:204

Chandra, Budiman. 2013. Pengantar Kesehatan Lingkungan. Jakarta : EGC.

Depkes, RI. 2013. Pedoman Pemberantasan Penyakit Diare. Jakarta : Ditjen PPM dan PL.

Kanaf, Andreas \& Petrus, 2011. Pembangunan Sarana Air Bersih Berbasis Masyarakat. Jakarta : GIZ

Notoatmodjo, S, 2014. Pendidikan dan Perilaku Kesehatan. Jakarta : Rineka Cipta.

Sander, M.A., 2005. Hubungan Faktor Sosial Budaya dengan Kejadian Diare di Desa Candinegoro Wonoayu Sidoarjo. 
Dinamika Kesehatan Jurnal Kebidanan dan Keperawatan Vol 10 No. 2 Desember 2019 ( ISSN: 2086-3454 EISSN: 2549-4058) url: http://ojs.dinamikakesehatan.unism.ac.id DOI: https://doi.org/10.33859/dksm.v10i2

Hubungan Kondisi Jamban Keluarga Dan Sarana Air Bersih Dengan Kejadian Diare Pada Balita Di Wilayah Kerja Puskesmas Arosbaya Bangkalan

Medika. Vol 2 No. 2 Juli 2005 : 163193.

Soebagyo, 2013. Diare Akut pada Anak. Surakarta : Universitas Sebelas Maret Press.

Soemirat, J. 2014. Kesehatan Lingkungan. Yogyakarta : Gadjah Mada University Press.

Timmreck, C.T, 2004. Epidemiologi Suatu Pengantar. Jakarta : EGC.

Widyastuti, P., 2005. Epidemiologi Suatu Pengantar Edisi 2. Jakarta : EGC. 